\title{
Sicilian potential biogas production
}

\author{
Antonio Comparetti, ${ }^{1}$ Pierluigi Febo, ${ }^{1}$ Carlo Greco, ${ }^{1}$ Santo Orlando, ${ }^{1}$ Kestutis Navickas, ${ }^{2}$ \\ Kestutis Venslauskas ${ }^{2}$
${ }^{1}$ Dipartimento di Scienze Agrarie e Forestali, Università degli Studi di Palermo, Italy; ${ }^{2}$ Institute of Energy and Biotechnology Engineering, Aleksandras Stulginskis University, Akademija, Kauno r., \\ Lithuania
}

\begin{abstract}
This study is aimed at predicting the Sicilian potential biogas production, using the Organic Fraction of Municipal Solid Waste (OFMSW), animal manure and food industry by-products, in a region where only one biogas plant using MSW and one co-digestion plant are nowadays available.

The statistical data about OFMSW, the number of animals bred in medium and large farms and the amounts of by-products of food processing industries were evaluated, in order to compute the Sicilian potential biogas and energy production. The OFMSW produced in Sicily, that is 0.8 million tons ca. per year ( $37 \%$ of MSW), could be used in a bio-reactor, together with other raw materials, for Anaerobic Digestion (AD) process, producing biogas and "digestate". Moreover, 3.03 million tons ca. of manure, collected in medium and large animal husbandry farms (where cows, pigs and poultry are bred), and 350 thousand tons ca. of by-products, collected in food processing industries (pomace from olive oil mills and grape marc from wineries), might be used for AD process.

The Sicilian potential biogas production from the $\mathrm{AD}$ of the above
\end{abstract}

Correspondence: Antonio Comparetti, Dipartimento di Scienze Agrarie e Forestali, Università degli Studi di Palermo, Viale delle Scienze, Building 4, 90128 Palermo, Italy.

Tel. +39.091 .23897057 - Fax: +39.091 .484035 .

E-mail: antonio.comparetti@unipa.it

Key words: animal manure, co-digestion, energy, food industry by-products, Organic Fraction of Municipal Solid Waste.

Contributions: the authors contributed equally.

Conflict of interests: the authors declare no potential conflict of interests.

\section{Acknowledgements}

The authors acknowledge Dr. Silvia Coscienza, Head of the Waste Department of Sicilian Region, and Francesco Ribaudo, Mayor of Marineo town (Palermo), for their collaboration in data collection.

(O) Copyright A. Comparetti et al., 2013

Licensee PAGEPress, Italy

Journal of Agricultural Engineering 2013; XLIV(s2):e103

doi:10.4081/jae.2013.s2.e103

This article is distributed under the terms of the Creative Commons Attribution Noncommercial License (by-nc 3.0) which permits any noncommercial use, distribution, and reproduction in any medium, provided the original author(s) and source are credited. raw materials is 170.2 millions of $\mathrm{m}^{3}$, that is equal to $1023.4 \mathrm{GWh}$ of energy per year, of which $484 \mathrm{GWh}$ from animal manure, $303 \mathrm{GWh}$ from OFMSW and $236.4 \mathrm{GWh}$ from food industry by-products. The highest biogas production is in the province of Palermo ( 35.6 millions of $\mathrm{m}^{3}$ ), Ragusa (30.8 millions of $\mathrm{m}^{3}$ ) and Catania (22.8 millions of $\mathrm{m}^{3}$ ), having a potential energy production of $213.8,185$ and $137 \mathrm{GWh}$, respectively.

\section{Introduction}

The biogas produced in a reactor at the end of Anaerobic Digestion (AD) process can be used for the extraction of methane, that can be transferred to the natural gas distribution pipeline or used as vehicle fuel. Another option is to transform the biogas produced into electric and/or thermal energy, in order to contribute to replace fossil-oil based energy sources with renewable ones.

Instead, the other product of $\mathrm{AD}$ process, that is the digested substrate or "digestate", is generally separated into a solid and a liquid fraction. The solid fraction can be used as an organic substrate for greenhouse cultivation, while, according to the EU Nitrate Directive (91/676/EEC), the liquid fraction having a chemical composition suitable for plant nutrition can be spread on soils as an organic fertiliser (EU, 1991), in order to minimise the applied rates of nitrogen mineral fertilisers (Weiland, 2010).

The $\mathrm{AD}$ process is able to significantly reduce bad smells (up to $80 \%$ ) and positively change the composition of odours (Weiland, 2010), inactivate weed seeds, bacteria (e.g. Salmonella spp., Escherichia coli, Listeria spp.), viruses, fungi and other parasites in the feedstock (Strauch and Philipp, 2000; Sahlström, 2003).

If a mixture of the Organic Fraction of Municipal Solid Waste (OFMSW), animal manure and food industry by-products, eventually together with herbaceous energy plants and other raw materials, are used for $\mathrm{AD}$, the biogas yield can be increased (Piccinini et al., 2008). Investigations and practical experience show that mixtures of industrial organic wastes with agricultural production ones or plant biomass determine the following benefits: to improve the $\mathrm{AD}$ process, so that the digestate can be enriched with various compounds having properties more suitable for plant fertilisation; to increase the biogas yield and, therefore, the biogas plant profitability (Navickas et al., 2004, 2005). Furthermore, after the anaerobic co-digestion, it is possible to minimise the problems related to the collection of some wastes (e.g. OFMSW, animal manure, sewage sludge, wastes of slaughter houses), i.e. bad smell (due to the concentration of proteins and sulphuric compounds) and high nitrogen concentration (Comparetti et al., 2012).

In Sicily (Italy) about 5 millions of inhabitants (ISTAT, 2012) produce about 2 million tons of Municipal Solid Waste (MSW) per year, of which the 37\% can represent the Organic Fraction (OFMSW), and the OFMSW treated is only about the $3 \%$ of MSW (Sicilian Region, 2011). The OFMSW could be used in a bio-reactor, together with other raw 
materials, in order to produce biogas and "digestate", in a region where only one biogas plant using MSW is operating at the landfill of Palermo (Sicilian Region, 2012) and one co-digestion plant is available at Marianopoli (Caltanissetta). Moreover, in Sicily, the manure produced in medium and large animal husbandry farms (breeding cows, pigs, poultry, etc.) and the by-products of food processing industries (e.g. pomace from olive oil mills and grape marc from wineries) would constitute the mixture usable for biogas production (Piccinini et al., 2008).

In this perspective the aim of this study is to predict the Sicilian potential biogas production, using the above unmarketable raw materials, i.e. OFMSW, animal manure and food industry by-products.

\section{Materials and Methods}

The statistical data about OFMSW, the number of animals bred in medium and large farms and the amounts of by-products of food processing industries were evaluated, in order to compute the Sicilian potential biogas and energy production.

The potential biogas production per year from OFMSW ( $B_{\text {OFMSW }}$ ) was determined according to the following equation, based on the biogas yield $\left(b_{w}\right)$ (Bolzonella et al., 2006) and the mass of this fraction produced per year :

$B_{\text {OFMSW }}=b_{w} \cdot m_{w}$

where : $b_{w}$ is the biogas yield of OFMSW $\left(\mathrm{m}^{3} \cdot \mathrm{t}^{-1}\right)$;

(Eq. 1)

$m_{w}$ is OFMSW mass (t).

The potential energy production per year from OFMSW ( $\left.E_{\text {OFMSW }}\right)$ was determined according to the following equation :

$E_{\text {OFMSW }}=B_{\text {OFMSW }} e_{b}$

where : $B_{\text {OFMSW }}$ is the potential biogas production from OFMSW $\left(\mathrm{m}^{3}\right)$;

$e_{b}$ is the energetic value of biogas, depending on the methane concentration in biogas $\left(\mathrm{kWh} \cdot \mathrm{m}^{-3}\right)$.

In order to determine the potential biogas production from OFMSW, only the $40 \%$ of this fraction produced and collected in Sicily was considered to be used for anaerobic co-digestion process.

The mass of manure produced by each animal species was computed by multiplying the mass of manure produced by each animal (Navickas et al., 2009) per the number of cows, pigs and poultry, drawn from the $6^{\text {th }}$ General Census of Agriculture (ISTAT, 2011).
The potential biogas production per year from animal manure $\left(B_{m}\right)$ was determined according to the following equation, based on the biogas yield $\left(b_{m}\right)$ (Navickas et al., 2009) and the mass of manure $\left(m_{m}\right)$ of each animal species :

$B_{m}=b_{m} \cdot m_{m}$

In order to compute the potential biogas production from manure, only the manure produced and collected in medium and large farms (having a minimum number of 50 cows or 100 pigs or 1000 poultry units) was considered to be used for anaerobic co-digestion process.

The potential energy production per year from animal manure $\left(E_{m}\right)$ was determined according to the following equation :

$E_{m}=B_{m} \quad e_{b}$ where : $B_{m}$ is the potential biogas production from manure $\left(\mathrm{m}^{3}\right)$.

The potential biogas production per year from food industry by-products (pomace from olive oil mills and grape marc from wine making plants) $\left(B_{b}\right)$ was computed using the following equation, based on the biogas yield $\left(b_{m}\right)$ (Piccinini et al., 2008) and the mass $\left(m_{b}\right)$ of each byproduct type (ISTAT, 2011) :

$$
B_{b}=b_{b} \cdot m_{b}
$$

The potential energy production per year from food industry by-products $\left(B_{b}\right)$ was determined according to the following equation :

$$
E_{b}=B_{b} \quad e_{b}
$$

\section{Results and discussion}

In Sicily 5.05 millions ca. of inhabitants (ISTAT, 2012) produce 2.15 million tons ca. of Municipal Solid Waste (MSW) per year, of which $37 \%$ ( 0.8 million tons ca.) can represent the Organic Fraction (OFMSW). At present only 0.07 million tons ca. of OFMSW ( $3.17 \%$ of MSW) are treated (Sicilian Region, 2011), while 315.3 thousand tons per year of this fraction might be used for biogas production.

Moreover, 3.03 million tons ca. of manure, collected in medium and large animal husbandry farms (where cows, pigs and poultry are bred), and 350 thousand tons ca. of by-products, collected in food processing industries (pomace from olive oil mills and grape marc from wineries), might be used for $\mathrm{AD}$ process.

The Sicilian potential biogas production is 170.2 millions of $\mathrm{m}^{3}$, that

Table 1. Mass, potential biogas and energy production from OFMSW, animal manure and food industry by-products, both in the nine provinces of Sicily

\begin{tabular}{|c|c|c|c|c|c|c|c|c|c|}
\hline \multirow[t]{2}{*}{ Provinces } & \multicolumn{3}{|c|}{ OFMSW } & \multicolumn{3}{|c|}{ Animal manure } & \multicolumn{3}{|c|}{ Food industry by-products } \\
\hline & $\begin{array}{l}\text { Mass } \\
10^{3} \mathrm{t}^{-1}\end{array}$ & $\begin{array}{l}\text { Biogas } \\
10^{6} \mathrm{~m}^{3}\end{array}$ & $\begin{array}{l}\text { Energy } \\
\text { GWh }\end{array}$ & $\begin{array}{l}\text { Mass } \\
10^{3} \mathrm{t} \mathrm{y}^{-1}\end{array}$ & $\begin{array}{l}\text { Biogas } \\
10^{6} \mathrm{~m}^{3}\end{array}$ & $\begin{array}{l}\text { Energy } \\
\text { GWh }\end{array}$ & $\begin{array}{c}\text { Mass } \\
103 \mathrm{t} \mathrm{y}^{-1}\end{array}$ & $\begin{array}{l}\text { Biogas } \\
106 \mathrm{~m}^{3}\end{array}$ & $\begin{array}{c}\text { Energy } \\
\text { GWh }\end{array}$ \\
\hline Agrigento & 26.6 & 4.3 & 25.8 & 52.6 & 1.3 & 8.0 & 47.4 & 5.0 & 30.0 \\
\hline Caltanissetta & 15.4 & 2.5 & 15.0 & 85.5 & 2.1 & 13.0 & 22.1 & 2.6 & 15.6 \\
\hline Catania & 75.0 & 12.0 & 72.0 & 302.0 & 7.8 & 47.0 & 31.6 & 3.0 & 18.0 \\
\hline Enna & 8.6 & 1.4 & 8.4 & 409.3 & 10.2 & 61.0 & 12.7 & 1.2 & 7.2 \\
\hline Messina & 40.6 & 6.5 & 39.0 & 311.3 & 7.8 & 47.0 & 15.5 & 1.5 & 9.0 \\
\hline Palermo & 82.1 & 13.1 & 78.6 & 574.2 & 14.8 & 89.0 & 67.6 & 7.7 & 46.2 \\
\hline Ragusa & 16.4 & 2.6 & 15.6 & 924.8 & 26.8 & 161.0 & 13.2 & 1.4 & 8.4 \\
\hline Siracusa & 25.1 & 4.0 & 24.0 & 344.6 & 8.8 & 53.0 & 16.4 & 1.6 & 9.6 \\
\hline Trapani & 25.5 & 4.1 & 24.6 & 28.7 & 0.7 & 5.0 & 124.0 & 15.4 & 92.4 \\
\hline SICILY & 315.3 & 50.5 & 303.0 & 3033.0 & 80.3 & 484.0 & 350.2 & 39.4 & 236.4 \\
\hline
\end{tabular}
and in the whole region. 


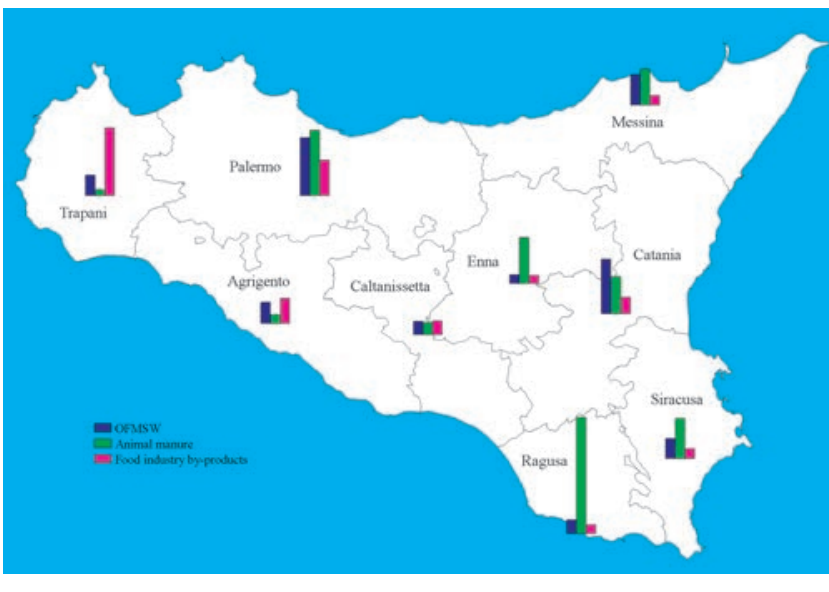

Figure 1. Potential energy production from biogas in the nine provinces of Sicily (GWh).

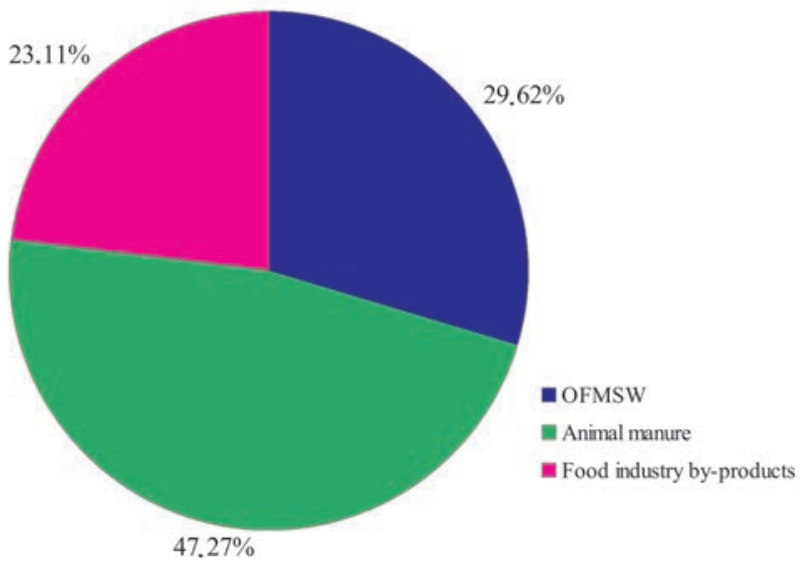

Figure 2. Distribution of Sicilian potential energy production from biogas among the raw materials surveyed.

is equal to $1023.4 \mathrm{GWh}$ of energy per year, of which $484 \mathrm{GWh}$ from animal manure, $303 \mathrm{GWh}$ from OFMSW and $236.4 \mathrm{GWh}$ from food industry by-products.

The highest potential biogas production from the above mixture is in the provinces of Palermo (35.6 millions of $\mathrm{m}^{3}$, equal to $213.8 \mathrm{GWh}$ per year), Ragusa (30.8 millions of $\mathrm{m}^{3}$, equal to $185 \mathrm{GWh}$ per year) and Catania (22.8 millions of $\mathrm{m}^{3}$, equal to $137 \mathrm{GWh}$ per year).

The mass of OFMSW, the manure produced in medium and large animal husbandry farms and food industry by-products, as well as the potential biogas and energy production from these raw materials in Sicily are shown in Table 1.

The potential energy production from OFMSW, animal manure and food industry by-products in the nine provinces of Sicily and in the whole region are presented in Figures 1 and 2, respectively.

The highest potential energy production from OFMSW is in the province of Palermo, due to the highest number of inhabitants and an efficient separate waste collection.

Moreover, the highest potential energy production from manure is in the province of Ragusa, because of the most intensive animal husbandry.
Furthermore, the highest potential energy production from food industry by-products is in the province of Trapani, due to the highest number of food processing industries.

The $\mathrm{AD}$ of the mixture surveyed in this study, mainly constituted by animal manure (47\%) but also by OFMSW (30\%) and food industry byproducts $(23 \%)$, would produce 170.2 million $\mathrm{m}^{3}$ of biogas, that are equal to $1023.4 \mathrm{GWh}$ per year.

\section{Conclusions}

The calculated mass of OFMSW, animal manure and food industry by-products in Sicily is $315.3,3033$ and 350.2 thousand tonnes per year, respectively.

The Sicilian potential biogas production from OFMSW, animal manure and food industry by-products is 50.5, 80.3 and 39.4 million of $\mathrm{m}^{3}$ of biogas per year, respectively.

The Sicilian total potential biogas production is 170.2 million of $\mathrm{m}^{3}$ of biogas, that is equal to $1023.4 \mathrm{GWh}$ per year.

The best possibilities for biogas production are in the provinces of Palermo, Ragusa and Catania, having a potential energy production of $213.8,185$ and $137 \mathrm{GWh}$, respectively.

Waste management is nowadays a problem to be solved in Sicily, as well as in the rest of Italy. In fact, the landfill sites have been or will be filled in with MSW very soon in Italy, where people don't accept the use of new sites in their municipal land. Moreover, the measures aimed at promoting segregated waste collection have been only scarcely implemented in Sicily, as well as in the whole Italy, where the environmentalist movements always fight against the building of incinerators. Therefore, the inefficient waste management has often caused public health problems in whole cities, like recently in Palermo.

In this perspective politicians should promote the valorisation of organic wastes (e.g. OFMSW, animal manure and food industry by-products) through $\mathrm{AD}$ process. In fact, whether organic wastes were anaerobically digested, it would highly reduce the amounts of these wastes that are nowadays aerobically composted or spread on land as bio-fertilisers after purification or, even worse, landfilled. Therefore, politicians should promote the building of co-digestion plants also in Sicily, in order to contribute to reduce $\mathrm{CO}_{2}$ emission and, as a consequence, global warming.

\section{References}

Bolzonella D., Pavan P., Mace S., Cecchi F. 2006. Dry anaerobic digestion of differently sorted organic municipal solid waste: a full-scale experience. Water Sci Technol 53(8):23-32.

Comparetti A., Greco C., Navickas K., Venslauskas K. 2012. Evaluation of potential biogas production in Sicily. Proceedings of the $11^{\text {th }}$ Int. Scient. Conf. "Engineering for Rural Development", Jelgava, Latvia, 24-25 May, pp. 555-559.

European Union, 1991. Council Directive 91/676/EEC concerning the protection of water against pollution caused by nitrates from agricultural sources. In: Official Journal of the European Communities, 12, pp 1-8.

ISTAT - National Institute of Statistics. 2011. $6^{\text {th }}$ General Census of Agriculture. Sicilian Region.

ISTAT - National Institute of Statistics. 2012. We Italy, 100 statistics to understand the country in which we live. pp. 1-13.

Navickas K., Župerka V., Venslauskas K. 2004. Bioduju gamyba iš organiniu atlieku ir kulturiniu augalu. Šilumos energetika ir technologijos, KTU, pp. 277-282. 
Navickas K., Venslauskas K., Župerka V. 2005. Pieno produktu gamybos atlieku anaerobinis perdirbimas. Žmogaus ir gamtos sauga. LŽUU, pp. 46-48.

Navickas K., Venslauskas K., Zuperka V. 2009. Potential and possibilities of biogas production from agricultural raw materials in Lithuania. Rural Development 2009. Lithuanian

University of Agriculture, pp. 365-369.

Piccinini S., Bonazzi G., Fabbri C., Sassi D., Schiff M., Soldano M., Verzellesi F., Berton M. 2008. Energy from biogas produced from livestock manure, dedicated biomass and wastes. Funded by the Autonomous Region Friuli Venezia Giulia, Rural Development Programme 2007-2013, pp. 1-21.
Sicilian Region, Department of Water and Wastes. 2011. Waste Report 2011.

Sicilian Region, Department of Energy. 2012. Energy Report 2011. Energy data in Sicily, pp. 1-122.

Sahlström L. 2003. A review of survival of pathogenic bacteria in organic waste used in biogas plants. Bioresource Technol 87:161-6.

Strauch D., Philipp W. 2000. Hygieneaspekte der biologischen Abfallbehandlung undverwertung. In: Bidlingmaier W. (Ed.) Biologische Abfallbehandlung, Eugen Ulmer, Stuttgart, Germany, pp. 155-208.

Weiland P. 2010. Biogas production: current state and perspectives. Appl Microbiol Biot 85:849-60. 